\title{
MANAGEMENT OF THE CONFLICT FOR ENTREPRENEURIAL INNOVATION AT A TRANSNATIONAL COMPANY LOCATED IN MEXICO
}

\author{
Tania Elena Gonzalez Alvarado \\ University of Guadalajara, Mexico \\ E-mail: tania.gonzalez@cucea.udg.mx \\ José Sánchez Gutiérrez \\ University of Guadalajara, Mexico \\ E-mail: jsanchez@cucea.udg.mx \\ Submission: 05/12/2016 \\ Revision: 12/01/2017 \\ Accept: 10/02/2017
}

\section{ABSTRACT}

The objective of this work is to analyze how conflict gives way to entrepreneurial innovation as a result of facing the non-compatibility between universalism-particularism at the subsidiary of a transnational company located in Mexico. The evidence was obtained by means of a survey, interviews, analysis of electronic mails, minutes of work, project documents and systemic observation. For this research, the SPSS and the root cause analysis were required. Conflict derived from non-compatibility between Universalism and Particularism leads to a more accurate decision making process.

Keywords: value generation or creation; transnational enterprise; leadership; communication. 
INDEPENDENT JOURNAL OF MANAGEMENT \& PRODUCTION (IJM\&P)

http://www.ijmp.jor.br

V. 8, n. 3, July - September 2017

ISSN: 2236-269X

DOI: 10.14807/ijmp.v8i3.585

\section{INTRODUCTION}

This research is an analysis of conflict management in enterprises that have developed global operating criteria and set subsidiaries in several regions due to their expansion process, or to their search of cost reduction. Thus, the following question is presented in this work: how does conflict at the transnational enterprise located in Mexico make way to the entrepreneurial innovation as a consequence of universalism-particularism non-compatibility?

This particular case study is for the German exporting and manufacturing Industry Company. The relevance of this work lies in the creation of a conceptual framework that makes possible for the transnational enterprise in Mexico to find it economically appealing to get involved in the community. Therefore, reflecting its interest in a greater local investment, as compared to the consideration of the location as a mere exporting launching pad. The proposed research is aligned with the most recent studies, even more, it is placed at the cutting edge of the current knowledge (FRITSCH, 2015; GASCA; TORRES, 2014; GUSEYNOV; FADHIL, 2014; KATZ, 2014; MARÍN; STUBRIN; GIBBONS, 2014; NISTOR, 2014; TRAUTWEIN; KÖRNER, 2014; ESTEINOU, 2013; POSADA, 2013; PORTA, 2013; ROMERO, 2013; MUÑOZ, 2012; VERA-VASSALLO, 2012). The theoretical framework offers a model as a response to the research question presented in this area.

\subsection{Theoretical framework}

The mostly mentioned factor determining the decision of whether to invest abroad is considered to be defined by transaction costs (GASPAR, 2015; GASCA; TORRES, 2014; DE LA GARZA, 2014; GRAS, 2013; DUNNING, 1995). However, the localization decision is barely the principle to achieve more profit. Every organization that expands internationally faces the challenge of finding its way into a multicultural environment in which social and economic factors are more complex. This is so mainly because of the country-specific realities that are not very comprehensible for foreign officers or senior managers, even for the most experienced ones.

In the end, these factors have an impact on the transaction costs since they have an influence on the decision-making efficiency. The impact is usually negative when the senior manager only applies global rules without creating new strategies 
INDEPENDENT JOURNAL OF MANAGEMENT \& PRODUCTION (IJM\&P)

http://www.ijmp.jor.br

v. 8, n. 3, July - September 2017

ISSN: 2236-269X

DOI: 10.14807/ijmp.v8i3.585

that would allow him/her to adapt the organization to the new reality. Rigidity in the decision-making prevents the company from getting greater benefits, i.e. by increasing transaction costs of the establishment of competence links with the town or locality (MARTIN; GONZALEZ, 2009; GONZALEZ; STEGGEMANN, 2013).

According to Trompenaars (1998), the efficiency of an economic system depends on the capacity to define and apply universal rules, while still accepting exceptions to adapt to particular situations. 'Universalism' is the perception that a set of ideas and practices can be applied everywhere without modifications ( $T$ ). 'Universalism' goes beyond perception, derives in action and normalization of what "must be" universal. In contrast, 'particularism' focuses on the exceptional nature of current situations $(T)$.

'Particularism' is the action and normalization of what "must be" in accordance to what is specific. Circumstances show the adaptation of ideas and practices. The universalism-particularism concept is fundamental to the decision making process at senior levels, by management board officers or senior managers, and furthermore it is important to the economy, as it can be seen in the works of Durkheim (1912), Parsons (1951), Levy (1966), Seibel and Jaeger (1970); Seibel (1973), Deal and Kennedy (1982), Schein and Mader, (1995), Hofstede (1997), Trompenaars and Hampden (1998), Kras (2001), Robbins (2004), Lange and Manske (2004), Jurado and Calderón (2006), Gundert and others (2011).

Following the logic of Figure 1, the transaction costs for subsidiaries are mainly a reflection of what the foreign manager does when becoming involved and collaborating, either inside or outside the organization. Becoming involved demands permanent negotiation along the process because in reality the different objectives and perspectives of each economic agent lead to non-compatibility.

The complementarity comes from facing and transforming realities which are built toward the inner part of the link (in-group) due to the non-compatibility between the participating agents. In the case of the subsidiary, the officer is the one that needs to acknowledge the way in which the relations are intertwined both inside and outside the subsidiary, addressing the conflicts that may arise as an opportunity to build new value in the face of complementarity. 
INDEPENDENT JOURNAL OF MANAGEMENT \& PRODUCTION (IJM\&P)

http://www.ijmp.jor.br

V. 8, n. 3, July - September 2017

ISSN: 2236-269X

DOI: 10.14807/ijmp.v8i3.585

In face of a non-compatibility tensions arise. From tensions conflict comes up. When the conflict is properly managed, consequently, it can have better results. This is the main point of this analysis.

There is a wide variety of definitions for 'conflict' in the theories that study the causes and unfolding of conflicts. A wide vision is offered by Domínguez and García (2003), Silva (2008) and Alexander (1990). In turn, several authors associate the conflict with a non-compatibility when socializing or establishing links (LEE, 1964; DEUTSCH, 1973; MELUCCI \& MASSOLO, 1991; NICHOLSON, 1992; ROS \& SCHWARTZ, 1995; AHLBRECHT et al., 2009).

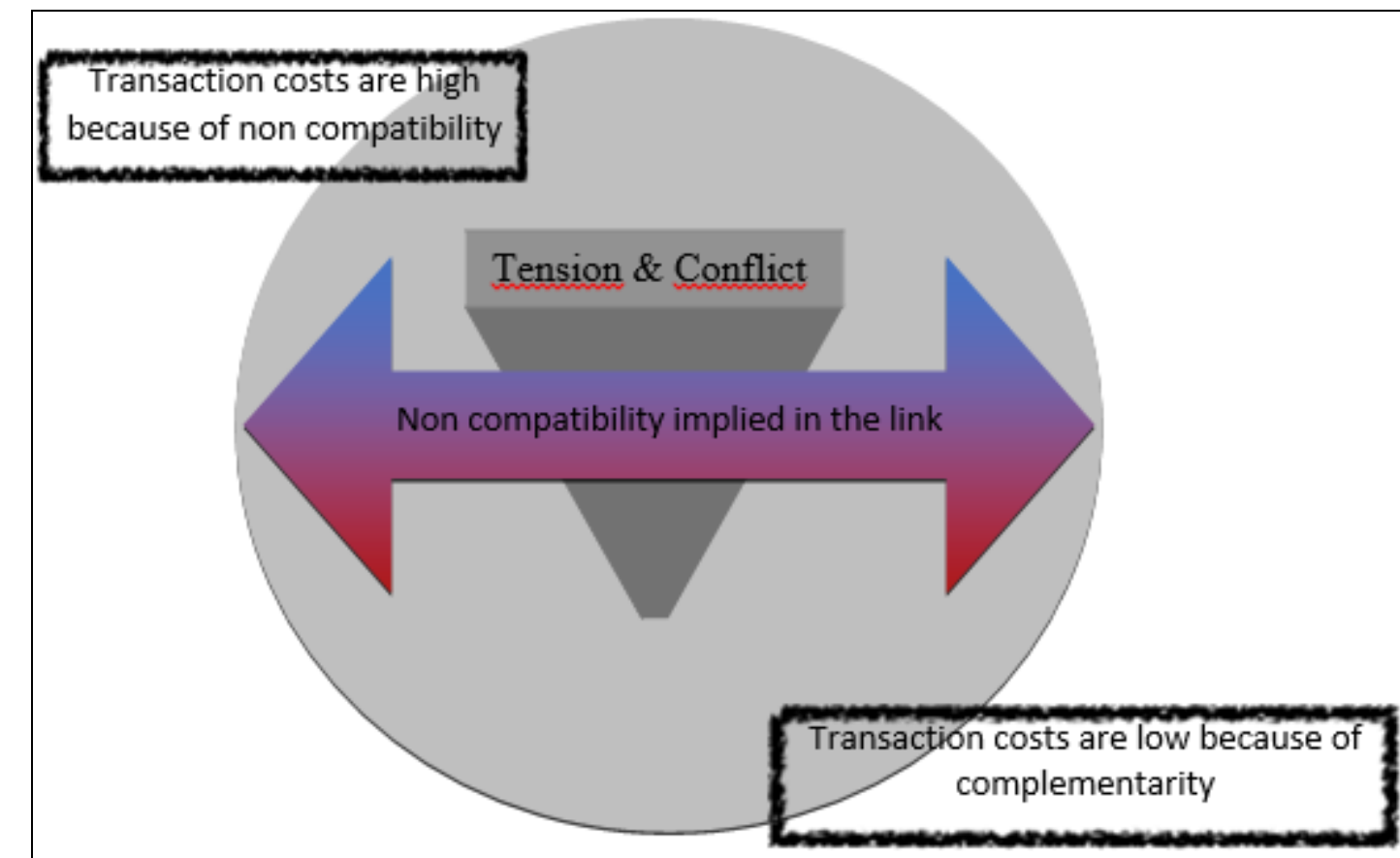

Figure 1: Management in face of complementarity because of non- compatibility issues

Source: Authors' own elaboration

The conflict unfolding process can be divided into three main stages: 1) potential conflict, characterized by the existence of non-compatible goals; 2) latent conflict, initiated by the perception of non-compatible goals among involved groups or individuals, with their new escalated stages (GLASL, 2004); and 3) manifested conflict.

As the model presented by figure 2 shows, each stage of the conflict matches a different management modality. The management of internal conflicts - which are frequently structural conflicts with an impact on the future economic value - is a responsibility of management. Proactive management means getting ahead of the 
conflict with a visionary process of change. Reactive management means that the conflict can no longer be avoided or ignored, thus turning into a crisis. Proactive or reactive actions are defined by the director's culture and by organizational multicultural background. During the potential phase of a conflict and the transitional stage of a potential for a latent conflict, in this research we talk about change management; a proactive visionary process, while in the latent and manifested conflict stage, we talk about management of a conflict under/in crisis and only as a reaction in face of what cannot be avoided or ignored.

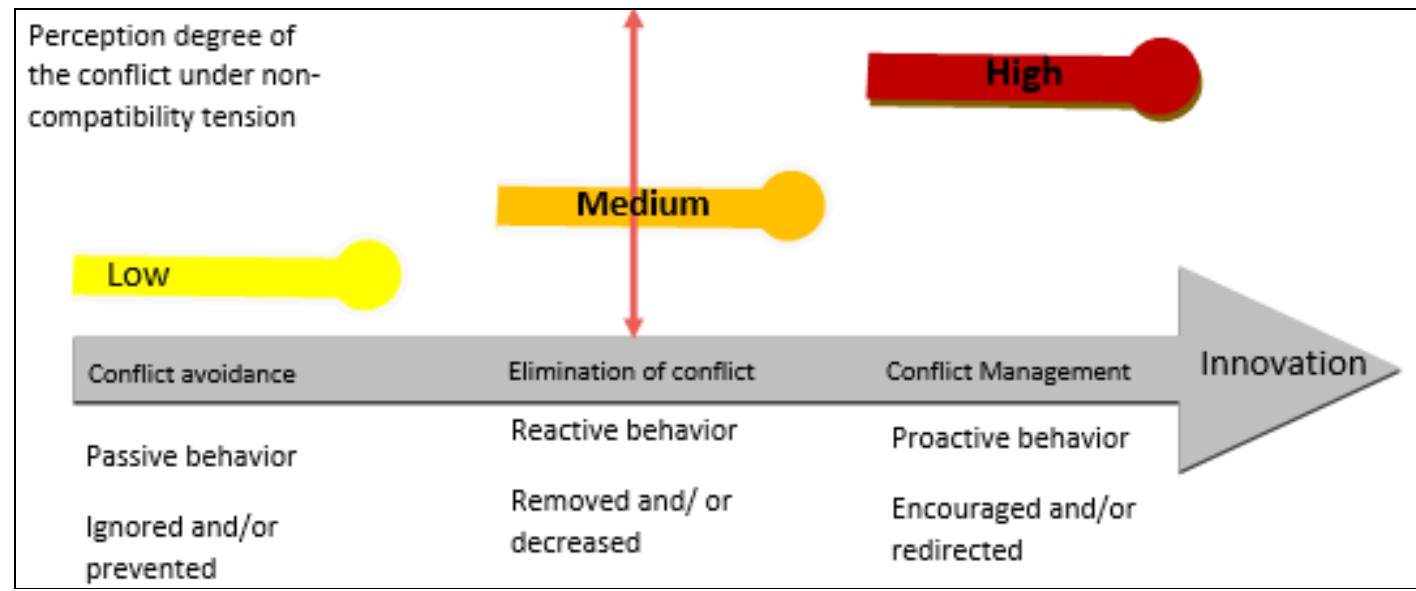

Figure 2: Conflict Management

Source: Authors' own elaboration

In the management of conflicts, the senior manager of the subsidiary faces the challenge of identifying at which level of the scale is the conflict located and what kind of conflict it is. In this way s/he can properly manage and channel it towards innovation.

The traditional management implies trying to minimize the destruction of intellectual capital caused by a non-functional conflict that distorts the phenomenon; furthermore, it entails trying to compulsively get to a win-lose solution. In other words, conflict management implies trying to rescue the company own economic value that has been lost due to the little will of cooperation among the affected parties, as a result of the lack of administration ability to manage the change (STEGGEMANN, 2015).

It happens only when there are negative effects for the reaching of financial aims. Whereas conflict management allows channeling it in a positive way. Unfortunately, at some companies, it is still a common practice to eliminate conflicts by making authoritative decisions and not necessarily by channeling them towards 
INDEPENDENT JOURNAL OF MANAGEMENT \& PRODUCTION (IJM\&P)

http://www.ijmp.jor.br

v. 8, n. 3, July - September 2017

ISSN: 2236-269X

DOI: 10.14807/ijmp.v8i3.585

innovation. But as Ahlbrecht and others (2009) described, conflict cannot be eliminated or overcome due to its endemic structure.

In the management of change, as a prevention step, the most important thing is communication that allows managing tensions and avoids the further unfolding of conflicts and non-functional solutions for the objectives of the organizations. The management of functional conflicts escalation, especially due to the tensions it entails, is vital for organizations. Functional conflicts imply the generation, maintenance and transference of behavioral patterns and cultural patterns to sustain the latent model for future generations, this is what Parsons calls latency. (STEGGEMANN, 2015)

At the organizational level, structures are tied tensions. Such structures may be rigid and require control in order to maintain what exists, and to exclude those who oppose to them; indeed, this is what is called 'latency' in the social system model of Parsons (1951). The result may be an authoritative and bureaucratic decision making style, as Seibel describes (1970).

Overcoming or eliminating conflicts by means of authoritative decisions, solves the short-term problem, but destroys intellectual capital in the long term, thus affecting the perception of those involved in organizational processes; what Seibel (1970) calls performance orientation conflict. Therefore, conflicts resolution in the organization by means of conversion of zero sum conflicts in the ones of variable or positive sum generates, in addition to the added economic value, an organizational culture of values with new perceptions of people involved, a valuable resource for leaders to guide perception and action while facing the change. (STEGGEMANN, 2015)

These functional conflicts with the tensions they imply, encourage innovation and transformation in the organization, so that the company can successfully manage its environment, get adapted to surroundings and adapt such surroundings to its needs. It results in an environment where economic factors are allocated in resolving and transforming reality, instead of adopting complex control processes to identify who is guilty; that can only distract the organization from achieving its goals. This kind of environment is the one that encourages innovative spaces. 
DOI: 10.14807/ijmp.v8i3.585

\section{RESEARCH METHODOLOGY}

One pilot questionnaire was developed and applied in order to understand if decision making at the subsidiary of a transnational enterprise operating in Mexico tends to be more universalist or more particularist, and to address from there the non-compatibility and its relationship with innovation.

This tool intention was to measure particularist quality regardless of universalist quality in analogy to Fincham's studies (1997). The differentiation between universalism and particularism as independent dimensions, allows the appearance of two additional categories located in between those that are regularly scored in the middle of a bipolar scale: those who achieve a high score both in universalism and in particularism are ambivalent, while those that achieve a low result in both of them can be described as indifferent.

It is supposed that the quality of the administrative mechanism is a function of it being oriented towards universalism or particularism. Thus, the quality of the administrative mechanism, whether it is universalism or particularism oriented, depends on the balance of both of them. In order to measure the attitude and to get to know it well, it is necessary to know how much universalist or particularist it is and make a balance between both of them.

By measuring the balance one can see what kind of administrative mechanism the analysed enterprises have. Based on who is a part of the body of officers or directors, one can know how universalist, particularist, ambivalent (an ambivalent perception of the administrative mechanism) or indifferent the subsidiary is.

No tool was found applied in previous studies to measure universalism regardless of particularism of the key people in a company in terms of two separated dimensions as Kaplan (1972) proposed. Therefore, a questionnaire was developed, modifying the questions proposed in the studies of Trompenaars (1998), Nawojczyk (2006), and Heumann (2010). The tool includes eight items developed for this research. 
Table 1: Pearson Correlation about the pilot questionnaire

\begin{tabular}{|c|c|c|c|c|c|c|c|c|c|}
\hline \multicolumn{10}{|c|}{ Correlations } \\
\hline \multirow{4}{*}{ item1 } & & Item & Item & Item & Item & Item & Item & Item & Item \\
\hline & & 1 & 2 & 3 & 4 & 5 & 6 & 7 & 8 \\
\hline & Pearson Correlation & 1 & .174 & .106 & .096 & -.029 & .107 & -.063 & .058 \\
\hline & Fol. (bilateral) & & .200 & .438 & .482 & .832 & .434 & .643 & .670 \\
\hline \multirow{3}{*}{ item2 } & $\mathrm{N}$ & 56 & 56 & 56 & 56 & 56 & 56 & 56 & 56 \\
\hline & Pearson Correlation & .174 & 1 & $.270^{*}$ & $.270^{*}$ & $-.287^{*}$ & -.168 & $-.331^{*}$ & -.077 \\
\hline & Fol. (bilateral) & .200 & & .044 & .044 & .032 & .216 & .013 & .574 \\
\hline \multirow{3}{*}{ item3 } & $\mathrm{N}$ & 56 & 56 & 56 & 56 & 56 & 56 & 56 & 56 \\
\hline & Pearson Correlation & .106 & $.270^{*}$ & 1 & $.328^{*}$ & $-.479^{* *}$ & -.127 & -.261 & -.145 \\
\hline & Fol. (bilateral) & .438 & .044 & & .014 & .000 & .349 & .052 & .288 \\
\hline \multirow{3}{*}{ Item4 } & $\mathrm{N}$ & 56 & 56 & 56 & 56 & 56 & 56 & 56 & 56 \\
\hline & Pearson Correlation & .096 & $.270^{*}$ & $.328^{*}$ & 1 & -.140 & -.108 & $-.355^{* *}$ & $-.314^{*}$ \\
\hline & Fol. (bilateral) & .482 & .044 & .014 & & .305 & .428 & .007 & .018 \\
\hline \multirow[b]{2}{*}{ item5 } & $\mathrm{N}$ & 56 & 56 & 56 & 56 & 56 & 56 & 56 & 56 \\
\hline & Pearson Correlation & -.029 & $-.287^{*}$ & $\begin{array}{c}- \\
.479^{*}\end{array}$ & -.140 & 1 & $.268^{*}$ & $.595^{* *}$ & .147 \\
\hline \multirow{4}{*}{ item6 } & Fol. (bilateral) & .832 & .032 & .000 & .305 & & .046 & .000 & .280 \\
\hline & $\mathrm{N}$ & 56 & 56 & 56 & 56 & 56 & 56 & 56 & 56 \\
\hline & Pearson Correlation & .107 & -.168 & $\begin{array}{c}- \\
.127\end{array}$ & -.108 & $.268^{*}$ & 1 & .081 & .210 \\
\hline & Fol. (bilateral) & .434 & .216 & .349 & .428 & .046 & & .552 & .121 \\
\hline \multirow{3}{*}{ item7 } & $\mathrm{N}$ & 56 & 56 & 56 & 56 & 56 & 56 & 56 & 56 \\
\hline & Pearson Correlation & -.063 & $-.331^{*}$ & -261 & $-.355^{* *}$ & $.595^{* *}$ & .081 & 1 & $.323^{*}$ \\
\hline & Fol. (bilateral) & .643 & .013 & .052 & .007 & .000 & .552 & & .015 \\
\hline \multirow{4}{*}{ Item8 } & $\mathrm{N}$ & 56 & 56 & 56 & 56 & 56 & 56 & 56 & 56 \\
\hline & Pearson Correlation & .058 & -.077 & - & $-.314^{*}$ & .147 & .210 & $.323^{*}$ & 1 \\
\hline & Fol. (bilateral) & .670 & .574 & .288 & .018 & .280 & .121 & .015 & \\
\hline & $\mathrm{N}$ & 56 & 56 & 56 & 56 & 56 & 56 & 56 & 56 \\
\hline
\end{tabular}

Source: Authors' own elaboration based on the results of the research project.

The questionnaire was applied as a pilot test in two German subsidiaries located in Mexico, at senior managers' level. They followed the desirable rules at work. Informers did not answer by saying 'no' although 'no' may have been true. Participants answered in a universalist way, even when in fact they act in a particularist way as Nawojczyk described (2006).

Those who were interviewed answered the way it was socially desirable. The responses given were the ones expected in the environment of the companies where they work, and they tried to answer rationally; but rationality does not exist in human beings a hundred per cent. Those who were interviewed are people working at a German enterprise, which have to agree with a series of 'issues' inside the company; therefore, they act as if they were uniformed. 
To ensure the instrument's validity and reliability, a large sample is needed so that it can produce a variance. Low variability of the responses showed that, in statistical terms, it was a biased sample. This lead authors to the enlargement of the sample, and all in all, variability did not change. The matrix of correlations shows that questions apparently are not related to one another.

Correlation is too low among the items; with exception of the relationship between items 5 and 3 and items 5 and 7, which is anyway not highly significant (Table 1). This implies relations that do not determine one another.

The items that were applied are not organized, but rather mixed as a sample of the matrix of rotated components (Table 2). This means that the items do not attain to the definition of the concepts of universalism and particularism of this research, and that one factor has not been clearly distinguished from the other one. By analysing the items in detail, we can see that these are items of social visibility and are hard to follow.

They were originally designed by Trompenaars (1998), Nawojczyk (2006), and Heumann (2010) for a bipolar analysis. However, the reality is not bipolar. The problem is not about the definition of concepts based on logical models, but about the approach to a reality in order to understand it. What is interesting, it is to see how non-compatibility in face of universalism-particularism creates tension, which, as time goes by, entails the conflict management for innovation and, with it, value generation.

Table 2: Matrix of rotated components

\begin{tabular}{ccc}
\hline \multicolumn{3}{c}{ Matrix of rotated components } \\
\hline $\mathbf{n}$ & 1 & Components \\
& -.223 & .496 \\
item1 & -.618 & .330 \\
item2 & -.708 & -.137 \\
item3 & -.247 & -.588 \\
Item4 & .820 & .097 \\
item5 & .193 & .590 \\
item6 & .781 & .193 \\
item7 & .008 & .661 \\
Item8 & Extraction method: analysis of main components. \\
Rotation method: Varimax normalization with Kaiser. \\
a. The rotation has converged in three iterations.
\end{tabular}

Source: Authors' own elaboration based on the results of the research project. 
The senior management team should fulfil the enterprise's objective, regardless of how much particularist or universalist the decisions taken may be. This could lead to different circumstances in terms of universalism-particularism. If the transnational enterprise proclaims universalism based decisions and at the subsidiary particularism based decisions are made, a performance conflict arises.

The senior management team finds it convenient to make particular particularism based decisions in order to create value, a greater competitiveness and profitability; but at the same time, it could destroy some intangible value or cause new unnecessary tensions at the operational level.

If, in addition to the senior management team, employees understand the decision-making process as a set of universal and particular rules, ambivalent or indifferent perceptions are created. For very particularist employees and a very particularist management, it seems that such conflict does not exist since they are 'set to the same channel'.

Such coincidence is difficult to be found when we have a multicultural organization, which is a part of a global enterprise with foreign capital; therefore, it is a company with a long-term vision that exceeds its own local reality.

A particularist management and an employee with a universalist background may cause a performance conflict, e.g. by the means of employee experimenting that a higher performance isn't necessarily giving as a result a greater reward due to particularist decisions at the management level (STEGGEMANN, 2015).

These circumstances, implying complex and unique patterns, make the measurement task for better understanding of the phenomenon, impossible. Under this analysis, we resort at this stage of the research to a study of a concrete reality a critical case.

The research took another turn for recovery and evidence analysis. This proof was gathered through work meetings, minutes, reports and projects that could make the decisions taken by the senior management team tangible; as well as their impact on collaborators and on the results of the project. The analysis focused on conflicts and tensions to find those facts subject to analysis that can derive in a response to the question. 


\section{ANALYSIS OF THE RESULTS}

The Root Cause Analysis (RCA) is a structural and systemic tool to locate flaws. RCA allowed identifying conflicts and tensions based on the facts. For the goals of this research, it comprised three steps: data collection, causing factors mapping and identification of the root cause (ROONEY; LEE, 2004).

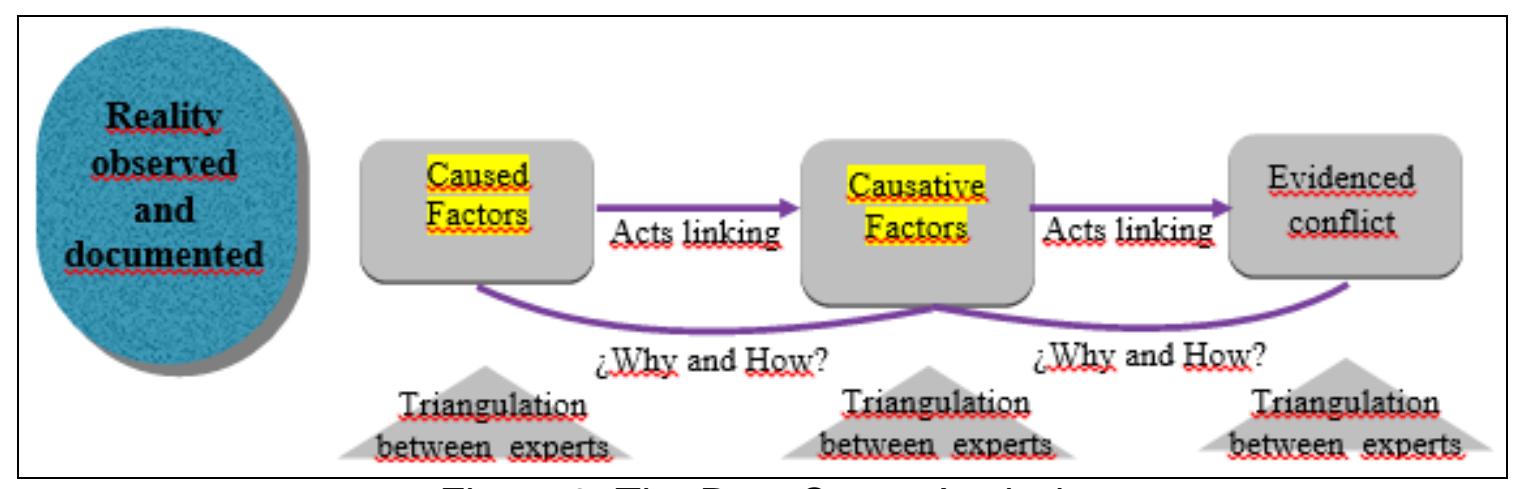

Figure 3. The Root Cause Analysis

Source: Authors' elaboration based on Rooney \& Lee (2004)

The critical case is the implementation of a quality management system (QMS) by means of a quality committee. Conflicts and tensions, involved in the implementation of a quality management system, were identified at the transnational subsidiary. During the research process, the coordination of the project was selected, as well as it correspondence to the internal quality committee and the external one with the person in charge of the project in Germany.

To make sure that the collected data were correct, the senior manager of the subsidiary was observed and interaction was held with him. Afterwards, information was organized and mapped based on causing factors; analysing and contrasting causes one by one based on the theoretical framework. Figure 3 shows the root cause of what was observed, following the reversed causal sequence of events.

An increase in the number of customer complaints was observed (RNC) (32). These complaints are related to an increase in the claims at the facilities (31), which lead to delays (34). At the same time, tensions are observed between the person in charge of the SGC implementation and area managers (35). These tensions are derived from the delays and time extensions in the internal processes of the company (34).

The delay that could be observed in the SGC implementation is not an exception. SGC adaptation is not moving appropriately forward at the subsidiary (37). Area audits have not improved from one year to the next (38). Delays, poor 
INDEPENDENT JOURNAL OF MANAGEMENT \& PRODUCTION (IJM\&P)

http://www.ijmp.jor.br

v. 8, n. 3, July - September 2017

ISSN: 2236-269X

DOI: 10.14807/ijmp.v8i3.585

audit results and a scarce participation of the senior management team, as well as the interest in the SGC system expressed by the ones in charge of the processes, lead to the same cause, which perceives SGC as a problem and not as a useful supporting system.

The system of the company inhibits its structure change and intervene, within the part of its environment that is not a part of the internal system or of its working area, by creating a vacuum to protect itself, as the Integration and Latency functions of the AGIL system of Parsons describe (STEGGEMANN, 2015).

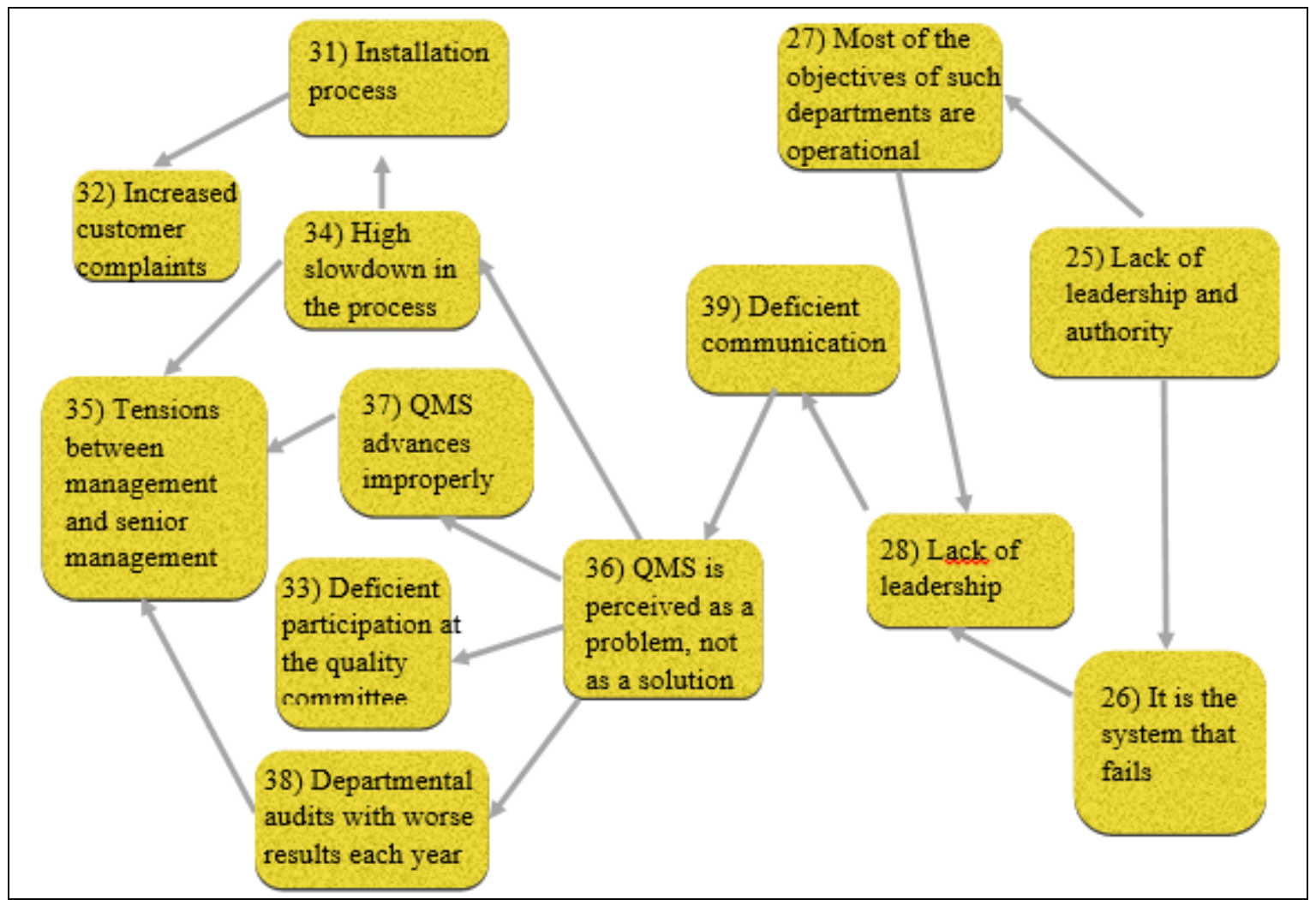

Figure 4: The Root Cause Analysis for the critical case Source: Steggemann (2015) modified by the authors.

Function I is directed towards the integration of inner differences that arise as a reaction to a changing environment by means of action patterns that control and guarantee the system's continuity. Function $L$ is focused on the formation and preservation of a system's identity or its working area by means of behavioural guidelines and rules that defend what already exists, thus guaranteeing the systems continuity (STEGGEMANN, 2015).

The aforementioned became visible with the introduction of the turtle form, which shows the inputs and outputs of each department and makes evident what people do or must do (38.) There is a confusion between working affairs and 
INDEPENDENT JOURNAL OF MANAGEMENT \& PRODUCTION (IJM\&P)

http://www.ijmp.jor.br

v. 8, n. 3, July - September 2017

ISSN: 2236-269X

DOI: 10.14807/ijmp.v8i3.585

personal affairs; the origin of a defensive behaviour is in a deficient inter and intra departmental communication.

Mainly, the origin of deficient communication is related to the lack of leadership at the company. There are few leaders and teams, and we can frequently observe bosses and groups of work (28), where intra department work is considered as necessary evil, similar to what had been seen in the previous project. 'It is the system that fails, not the person who leads the group'.

This kind of thought was developed due to a lack of clear and precise delimitations of the responsibility and authority of each person in their respective positions (26), focusing on products quality. In addition to confusion between working and personal affairs, there are gaps that people take over, or let others take over, depending on the circumstances.

This situation came up due to the lack of strategic objectives at departments level. Most of the objectives of such departments are operational, they are a part of their regular activity, they are internal, not strategic (27). This comes from a lack of leadership and authority (25) from senior management, visible due to the deficient participation at the quality committee of senior management and the managers of each department (33) (STEGGEMANN, 2015).

Senior level as well as department managers focus on delimiting and separating ( $\mathrm{I}$ and $\mathrm{L})$ to protect their comfort zone and their generated privileges ( $\mathrm{a}$ significant challenge for those involved); instead of looking for a balance of functions $A, G, I$ and $L$ of the Parsons scheme.

In other words, they should be searching for the balance between keeping and transferring behaviour patterns $(I)$ and stability $(L)$ through the organization, allowing at the same time the transformation of the organization to adapt to its environment and vice versa $(A)$ what could subsequently lead to the achievement of its goals (G) of profitability and competitiveness (STEGGEMANN, 2015).

The origin of orientation in delimitation and separation actions of a part of the team of department and of senior level managers needs to be deducted from the history of the company, from the established leadership forms, from structures and from the existing limits of how things are done inside and outside the organization, from its organizational culture (a weak organizational culture in the part of the sales) visible because of staff rotation and personnel's seniority levels. 
The system inhibits the change of its own structure and of the order of links between formal and informal groups. It interposes within its environment (that is not a part of the system), both boundaries and vacuums that are expressed through intradepartmental conflicts, at times ignored. Involved groups perceive that there is a significant challenge to protect their comfort zone and the privileges they have. Operational and non-strategic objectives, in combination with unclear goals, give as a result poorly committed working groups, whose communication is limited to demands for information instead of developing communication (STEGGEMANN, 2015).

What happens in this case, as in the other ones analysed in the company, is that they are focused on the elimination of mistakes during the final stage of processes: manufacturing, project management, quality control. It was also observed that, regarding control, conflicts and tensions must be rationally presented at the middle of the way.

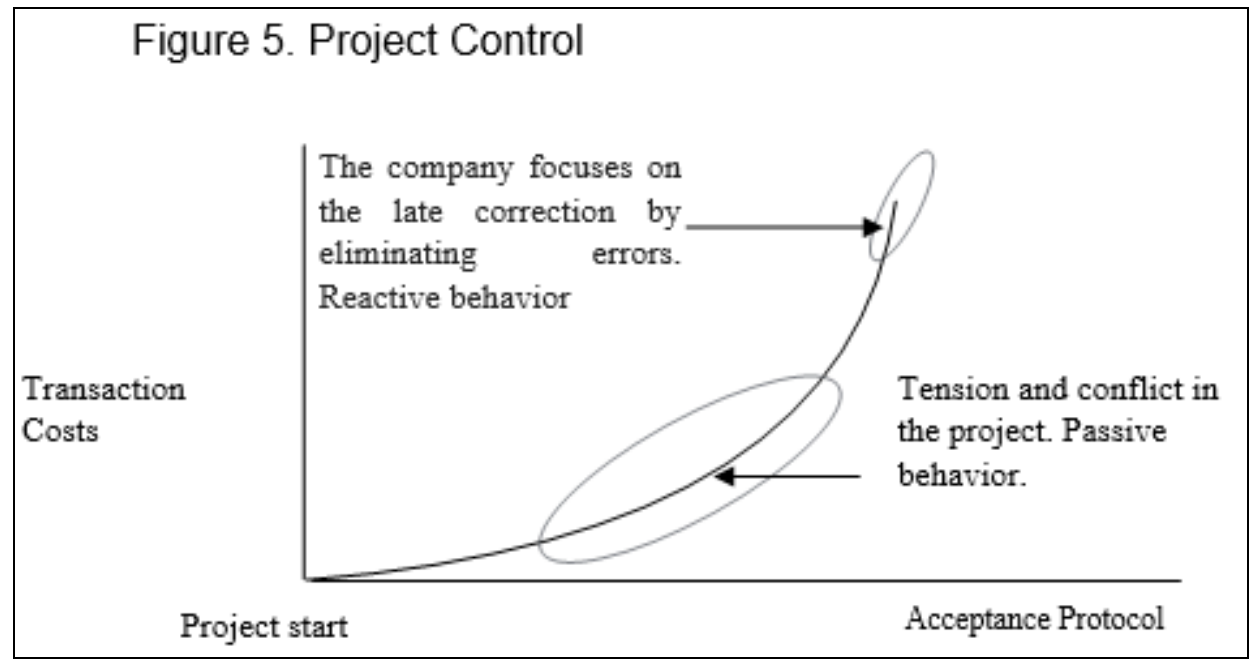

Figure 5. Project Control

Source: Steggemann (2015) modified by the authors.

The middle point is the representation of the conflict in figure 5. From the beginning, the planning-doing-verifying-acting process is initiated. If something unexpected is missing, people supervise the problem, take a lot of time to understand or grasp the situation and act with a delay.

But if something is missing at the end of the project, it is not related to the conflict. There can be seen the lack of total control. Thus, by the end of the project, we talk about a total lack of control during the process. It is the conflict evasion, a complementarity that is not in place there (STEGGEMANN, 2015). 
INDEPENDENT JOURNAL OF MANAGEMENT \& PRODUCTION (IJM\&P)

http://www.ijmp.jor.br

v. 8, n. 3, July - September 2017

ISSN: 2236-269X

DOI: 10.14807/ijmp.v8i3.585

The observations of the project reflect what is expected, i.e. what is founded by the theoretical framework. Action, games and conflict theories already have a certain age and apparently, they explain a great part of the observation; although Parsons did not work on the conflict. It can be that they were studied a long time ago, and they may have been abandoned or are not considered fashionable anymore; but it is a different question to consider them not important any longer (STEGGEMANN, 2015).

Some general traits can be identified from people interviewed and observations based on the theoretical framework. These traits deserve more attention to understand how complementarity is encouraged between universalismparticularism in face of non-compatibility for reaching the aim of innovation.

\section{CONCLUSIONS}

Broadening of horizons, thinking, feeling and interpreting reality in a different way works as long as they are within the limits established by society. Freedom exists within limits and rules (adaptation and latency). This set creates a sense of community to separate itself from something. This set allows also understanding in a context, within a reference framework. Crossing the limits to innovate causes conflicts. Therefore, making transparent what people do could cause non-favourable responses because it shows the non-compatibility that could apparently block the complementarity of universalism-particularism.

Transnational enterprises formally reflect a universal position to their employees; regardless of their geographic location. They create standards, bylaws and regulations that are intended to apply globally with the objective of not losing control and integration of their subsidiaries spread around the globe. However, during the day-to-day operations of each subsidiary, individuals in it, even those who come from the original country of the enterprise, are forced to take a combined stand where universalism and particularism seem to merge.

Universalism and particularism definitely complement each other from the moment in which the subsidiary involves people with different origins, visions and backgrounds. Since the subsidiary is an open system, external agents influence it as well. Socializing or relating, it creates tensions due to multidimensional heterogeneity of economic agents. The acknowledgement of tension and the possible management of conflicts arising from the non-compatibility between universalism and particularism 
lead to a more accurate decision making process. Furthermore, it leads to entrepreneurial innovation.

The opposite situation only encourages the search for individual interests, it discourages innovation and may lead to a competitiveness loss. The dangerous part lies in the human tendency to search and keep the comfort zone, regardless of how contradictory is this goal to manage a foreign subsidiary.

Victimizing a strategist during a conflict blocks the capacity to relearn from reality, thus innovating in the search of a greater value creation for the enterprise. It is required to acknowledge the non-compatibility to have more innovative enterprises, also to detect tensions, boost conflict and channel it towards the improvement of the organization; instead of ignoring the conflict or pretending to terminate it in an authoritative way.

This is a great challenge for senior management, given that they can control the media that boost all of them, but they cannot control other people's emotions and feelings. When the conflict is managed through directing it towards innovation, it entails the risk of deviating it towards the emotional part, leaving aside the intellectual conflict, which indeed does generate constructive changes to the subsidiary, the transnational enterprise, senior management and for employees in general.

\section{REFERENCES}

AHLBRECHT, K; BENDIEK, A.; MEYERS R.; WAGNER, S. (2007) Konfliktregelung und Friedenssicherung im internationalen System. Hagen: Fernuniversität in Hagen, Fakultät für Kultur- und Sozialwissenschaften.

\section{ALEXANDER, J. (1990) Las teorías sociológicas desde la segunda guerra mundial. Barcelona: Gedisa.}

DE LA GARZA, E. (2014) Empresas Trasnacionales, Discusiones Teóricas para su Estudio. Estrategias de relaciones laborales de las grandes corporaciones, v. 8, n. 12, p. 5.

DEAL, T.; KENNEDY, A. (1982) Corporate cultures. The rites and rituals of corporate life, Reading, Massachusetts: Addison-Wesley

DEUTSCH, M. (1973) The resolution of conflict: constructive and destructive processes. New Haven: Yale University Press.

DOMíNGUEZ, R.; GARCÍA, S. (2003) Introducción a la teoría del conflicto en las organizaciones. España: Universidad Rey Juan Carlos.

DUNNING, J. (1995) Reappraising the eclectic paradigm in an age of alliance capitalism. Austin: Journal of International Business Studies, p. 461-491. 
INDEPENDENT JOURNAL OF MANAGEMENT \& PRODUCTION (IJM\&P)

http://www.ijmp.jor.br

v. 8, n. 3, July - September 2017

ISSN: 2236-269X

DOI: 10.14807/ijmp.v8i3.585

DURKHEIM, E. (1912) Le suicide. Étude de sociologie. Paris.

ESTEINOU, J. (2013) La integración del Mercado Común Europeo-La transformación de los Medios de Comunicación. Signo y Pensamiento, v. 9, n. 17, p. 53-75.

FRITSCH, S. (2015) Technological innovation, globalization, and varieties of capitalism: the case of Siemens AG as example for contingent institutional adaptation. Business and Politics, v. 17, n. 1, p. 125-159.

GASCA, J.; TORRES, F. (2014) El control corporativo de la distribución de alimentos en México. Problemas del desarrollo, v. 45, n. 176, p. 133-155.

GASPAR, R. (2015) Los desafíos al desarrollo urbano-regional en la economía global contemporánea. Revista Urbano, v. 11, p. 17, p. 50-56.

GLASL, F. (2004) Das Kontingenz-Modell der Konfliktbehandlung. Alemania:

Perspektive Mediation, v. 1, n. 2, p. 82-87

GONZÁLEZ, T.; STEGGEMANN, M. (2013) Cooperación para la competitividad internacional: caso crítico-atípico. In GUTIÉRREZ, J. S. (coord.) La arquitectura financiera y desarrollo tecnológico para promover la competitividad, Universidad de Guadalajara, México, p. 227-252

GRAS, C. (2013) Expansión agrícola y agricultura empresarial: el caso Argentino. Revista de Ciencias Sociales, n. 32, p. 73-92.

GUNDERT, H.; KLINKE, S.; BLIESNER, A.; NAGLER, B. (2011) Betriebliche Vertrauenskulturen. Hintergrundpapier Landkarte RessourcenKultur. RessourcenKultur Paper, 3.

GUSEYNOV, A.; FADHIL, T. (2014) The main trends in the development of the corporate innovation systems. Life Science Journal, v. 11, n. 11s.

HOFSTEDE, G. (1997) Cultures and Organizations, London: McGraw-Hill.

JURADO, J.; CALDERÓN, G. (2006) Los dirigentes y el gobierno de las personas.

Argumentos Productivos, organizacionales y culturales. Revista Universidad Eafit, v. 42 , n. 144 , p. $34-50$

KATZ, C. (2014) Discutiendo la mundialización. Razón y Revolución, n. 5.

KRAS, E. (2001) La Administración Mexicana en transición. México: Grupo Editorial Iberoamericana

LANGE, H.; MANSKE, F. (2004) Kultur - ärgerlicher Passepartoutbegriff oder nützliche Kategorie der Gesellschaftsanalyse, in: LANGE, H.; MANSKE, F. (coord.):

Kultur im Verän-derungsprozess. Kultur als analytische Kategorie in der Arbeits- und Organisations-, der Innovations- und Umweltforschun, p. 227-248. Baden-Baden: Neue Verlagsgesellschaft

LEE, R. (1964) Religion and Social Conflict: An Introduction. LEE, R.; MARTY, M. (coord.) Religion and Social Conflict. New York, Oxford UP.

LEVY, M. (1966) Modernization and the structure of societies: A setting for international affairs (v. 1). Princeton: Princeton University Press.

MARÍN, A.; STUBRIN, L.; GIBBONS, M. (2014) Construyendo capacidades tecnológicas en escenarios inestables: empresas manufactureras argentinas y brasileñas. Revista de la CEPAL, n. 114, p. 163-182. 
MARTIN, M.; GONZÁLEZ, T. (2009) El vínculo empresarial en ausencia del mecanismo de cooperación y su impacto en el desarrollo. El caso de la industria de la confección mexicana, Revista Ciencias Sociales, Chile, Universidad Arturo Prat de lquique, n. 22

MELUCCI, A.; MASSOLO, A. (1991) La acción colectiva como construcción social. Estudios Sociológicos, p. 357-364.

MUÑOZ, J. (2012) Configuración organizativa de los Centros de Gobierno: Los casos de Alemania y Ecuador. Tercer Encuentro Anual de Sociedad Chilena de Políticas Públicas.

NICHOLSON, M. (1992) Rationality and the analysis of international conflict. v. 19. Cambridge: University Press.

NISTOR, C. (2014) Firms transnationalization. Evolution of multinational groups operating in Romania. SEA-Practical Application of Science, n. 5, p. 51-58.

PARSONS, T. (1951) El Sistema Social. Madrid: Alianza Editorial.

PORTA, F. (2013) Trayectorias de cambio estructural y enfoques de política industrial. ponencia presentada en el Seminario Neoestructuralismo y economía heterodoxa, Santiago de Chile: Cepal.

POSADA, E. (2013) Regiones e infraestructura en la integración suramericana. Si Somos Americanos, Revista de Estudios Transfronterizos, v. 13, n. 2, p. 113-140.

ROBBINS, S. (2004) Comportamiento organizacional. México: Pearson Educación.

ROMERO, A. (2013) El entorno internacional. Revista Tendencias, v. 1, n. 1.

ROS, M.; SCHWARTZ, S. (1995) Jerarquía de valores en países de la Europa Occidental: Una comparación transcultural. Reis, p. 69-88.

SEIBEL, H.; JAEGER, W. (1970) Leistung und Konflikt. Soziale Welt, v. 21, n. 1, p. 55-72.

SEIBEL, H. (1973) Folgen des Leistungskonflikts in der bürgerlichen Gesellschaft. Das Ar-gument, v. 15, n. 3, p. 123-143.

SILVA, G. (2008) La teoría del conflicto. Un marco teórico necesario.

Prolegómenos: derechos y valores, n. 22.

SCHEIN, E.; MADER, F. (1995) Unternehmenskultur: Ein Handbuch für Führungskräfte. Frankfurt: Campus Verlag.

STEGGEMANN, M. (2015) Complementariedad entre universalismo y particularismo en la empresa filial de la trasnacional alemana ubicada en México, Thesi (PhD in Administration). Mexico: Universidad La Salle.

TRAUTWEIN, H.; KÖRNER, F. (2014) German Economic Models, Transnationalization and European Imbalances (n. 28/2014). ZenTra-Center for Transnational Studies.

TROMPENAARS, F.; HAMPDEN-TURNER, CH. (1998) Riding the waves of culture. Understanding cultural diversity in Business. México: McGraw-Hill 
ISSN: 2236-269X

DOI: 10.14807/ijmp.v8i3.585

VERA-VASSALLO, A. (2012) Tecnología, competitividad internacional y desarrollo productivo de América Latina y el Caribe: algunas comparaciones con el Asia en desarrollo. Economía, v. 18, n. 35-36, p. 137-193. 